\title{
KETERAMPILAN MOTORIK PADA PENDIDIKAN JASMANI MENINGKATKAN PEMBELAJARAN GERAK SEUMUR HIDUP
}

\author{
Pinton Setya Mustafa ${ }^{1}$, Sugiharto ${ }^{2}$ \\ ${ }^{1}$ Universitas Negeri Malang, Pendidikan Olahraga, Malang, Indonesia \\ 2Universitas Negeri Malang, IImu Keolahragaan, Malang, Indonesia \\ pintonsetyamustafa@gmail.com, sugiharto@um.ac.id
}

\begin{abstract}
Motion is an inseparable activity in human life. By having good motor skills, it can support daily life. The purpose of this article is to discuss the characteristics of motor skills in humans. Motor skills can occur due to growth factors and individual circumstances that require to move. In the period of growth and development of motor skills tend to be explored and improved through physical education learning in schools. Physical education teachers become important agents in forming good motor skills in their students. Therefore understanding and implementation to provide services to students in improving motor skills is very important. Thus motor skills are one of the factors that can support human life in the future.
\end{abstract}

Keywords: motor skills, physical education, learning for life.

\begin{abstract}
Abstrak
Gerak merupakan aktivitas yang tidak dapat dipisahkan dalam kehidupan manusia. Dengan memiliki keterampilan motorik yang baik, maka dapat menunjang kehidupan sehari-hari. Tujuan artikel ini adalah membahas tentang karakteristik keterampilan motorik pada manusia. Keterampilan motorik dapat terjadi karena faktor pertumbuhan dan keadaan individu yang mengharuskan untuk bergerak. Dalam masa pertumbuhan dan perkembangan keterampilan motorik cenderung dieksplorasi dan ditingkatkan melalui pembelajaran pendidikan jasmani di sekolah. Guru pendidikan jasmani menjadi agen yang penting dalam membentuk keterampilan motorik yang baik pada peserta didiknya. Oleh karena itu pemahaman dan implementasi untuk memberikan layanan kepada peserta didik dalam meningkatkan keterampilan motorik sangat penting. Dengan demikian keterampilan motorik merupakan salah satu faktor yang dapat menunjang kehidupan manusia di masa mendatang.
\end{abstract}

Kata kunci: keterampilan motorik, pendidikan jasmani, belajar untuk hidup

\section{PENDAHULUAN}

Gerak merupakan elemen penting dalam kehidupan manusia. Gerak adalah ciri kehidupan serta memelihara gerak adalah mempertahankan hidup dan meningkatkan kemampuan gerak adalah meningkatkan kualitas hidup (Giriwijoyo \& Sidik, 2013: 87). Hampir semua aktivitas yang dilakukan manusia melibatkan unsur gerak atau keterampilan motorik. Sangat banyak aktivitas manusia yang melibatkan dimensi keterampilan motorik, misalnya dunia olahraga, dunia seni, serta beragam dunia kerja, dan profesi lainnya.

Pembelajaran keterampilan motorik adalah upaya pembelajaran yang berbasis pada

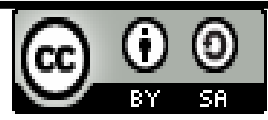

Volume 5, Nomor 2, September 2020 sportasaintika.ppj.unp.ac.id 
JURNAL SPORTA SAINTIKA

P-ISSN 2505-5651

E-ISSN 2579-5910

dimensi keterampilan motorik atau gerak. Karakteristik belajar antara lain: (1) suatu proses diperlukan untuk menyebabkan perubahan dalam kemampuan untuk menunjukkan performa dengan terampil, (2) terjadi sebagai akibat langsung dari latihan bukan karena pematangan atau perkembangan fisiologis secara langsung, (3) perubahan kinerja yang relatif permanen dalam kemampuan individu yang diamati (Haibach-Beach et al., 2018: 37-38). Sebenarnya hampir semua proses pembelajaran yang dilakukan manusia melibatkan unsur gerak. Intensitasnya saja yang berbeda-beda; dari yang sedikit hingga yang banyak. Pembelajaran Pendidikan Jasmani, Olahraga, dan Kesehatan (PJOK) merupakan salah satu wadah dalam mengaplikasikan pembelajaran keterampilan motorik di dalam satuan pendidikan (Mustafa et al., 2019: 1376). Selain itu PJOK adalah satu-satunya mata pelajaran di sekolah dimana anak-anak memiliki kesempatan untuk belajar keterampilan motorik dan memperoleh pengetahuan untuk berpartisipasi dalam berbagai aktivitas fisik (Le Masurier \& Corbin, 2006). Keterampilan motorik terdiri dari respons motorik dan persepsi yang diperoleh melalui belajar (Lutan, 1988: 95).

Pendidikan jasmani memberikan kompetensi dalam keterampilan motorik dan pola pergerakan yang dibutuhkan untuk melakukan berbagai aktivitas fisik dengan menggunakan beragam olahraga untuk mengembangkan kompetensi dalam keterampilan motorik yang akan bermanfaat untuk orang dewasa (Bert, 2010: 29; Mustafa \& Dwiyogo, 2020: 435). Keterampilan motorik berdasarkan otot dan tenaga yang digunakan terdiri dari motorik kasar dan motorik halus (Lutan, 1988: 97). Perkembangan motorik kasar anak lebih dulu dari pada motorik halus, misalnya anak akan lebih dulu memegang benda-benda yang ukuran besar dari pada ukuran yang kecil, sebab anak belum mampu mengontrol gerakan jari-jari tangannya untuk kemampuan motorik halusnya, seperti menggunting dan menggambar (Mitayani et al., 2015: 63). Perkembangan motorik kasar adalah elemen penting yang berkembang berdasarkan kronologi usia sehingga anak tidak dapat mencari kesulitan untuk mengikutsertakan tingkah laku motorik yang lebih kompleks pada usia yang lebih tinggi (Baharom et al., 2014: 129). Dengan demikian pembelajaran keterampilan motorik perlu diperhatikan dalam pelaksanaannya, sebab dapat berpengaruh di dalam masa depannya.

Peran pendidikan jasmani adalah bagian integral dari pendidikan melalui aktiftas jasmani yang bertujuan untuk meningkatkan individu secara organik, neuromuscular, intelektual, dan emosional melalui gerak insani yang dapat berupa aktivitas jasmani, permainan atau olahraga untuk mencapai tujuan pendidikan (Lutan, 1996: 7). Keterampilan motorik bekerja dengan baik dipengaruhi oleh koordinasi neuromuskuler. Koordinasi neuromuskuler adalah setiap gerak yang terjadi dalam urutan dan waktu yang tepat serta 
JURNAL SPORTA SAINTIKA

P-ISSN 2505-5651

E-ISSN 2579-5910

gerakannya mengandung tenaga yang timbul oleh kontraksi otot, dan otot berkontraksi karena adanya perintah yang diterima melalui sistem syaraf (Schmidt, 1988: 265).

Pembelajaran keterampilan motorik baik dalam teoritis maupun praktis merupakan bagian penting dari proses pendidikan dan pembelajaran yang perlu untuk dieksplorasi dan dikuasai. Pembelajaran keterampilan motorik punya sumbangsih nyata untuk mensukseskan proses pendidikan dan pembelajaran itu sendiri yang bermuara pada terciptanya subyek didik yang mampu mengembangkan potensinya secara maksimal (Mustafa \& Winarno, 2020: 2). Namun kenyataannya pembelajaran keterampilan motorik di satuan pendidikan dasar dan menengah sering dipandang sebelah mata, misalnya pembelajaran PJOK salah satu pembelajaran keterampilan motorik dianggap mengganggu oleh pembelajaran lain bahkan dihilangkan jika mendekati pekan ujian akhir sekolah (Giriwijoyo \& Sidik, 2013: 72). Padahal tujuan dari PJOK adalah untuk memberi para siswa keterampilan motorik yang akan memungkinkan siswa untuk berpartisipasi dalam berbagai aktivitas fisik sekarang dan seumur hidup (Le Masurier \& Corbin, 2006).

Selanjutnya apabila peserta didik yang meninggalkan sekolah dasar tanpa dasar keterampilan motorik yang kuat (tertinggal) mereka sama seperti pergi tanpa kemampuan bahasa atau matematika serta berdampak dalam belajar keterampilan baru juga akan tertinggal. Sebagai profesi, PJOK perlu melawan mitos pematangan dan mengajarkan keterampilan motorik dari anak prasekolah sampai SMA (Clark, 2007: 39). Perkembangan motorik anak dipengaruhi secara positif oleh kualitas stimulasi psikososial dengan cara kelompok bermain di rumah serta kelengkapan sarana dan prasarana sekolah, dan faktor umur anak. Sedangkan program pengajaran yang semakin beragam memberikan pengaruh negatif pada perkembangan motorik anak (Hastuti, 2009: 55). Selain itu Penanaman disiplin, jujur, tanggung jawab, dan kerjasama lebih mudah dilakukan dan dibentuk melalui kegiatan bermain, bukan disajikan secara teoritik sebab dengan bermain seseorang akan kelihatan karakternya, apakah dia disiplin, jujur, tanggung jawab, dan kerjasama atau tidak (Winarno, 2012: 6). Sehingga dapat dikatakan dari ruang lingkup pendidikan jasmani yaitu belajar gerak keterampilan motorik melalui permainan dapat berpengaruh terhadap perilaku psikososial. Namun kenyataannya sangat memprihatinkan karena pembelajaran keterampilan motorik dalam pendidikan jasmani sering kali diabaikan. Padahal dengan kegiatan pembelajaran keterampilan motorik yang memadai, seseorang diharapkan mampu menjalani kehidupan dengan baik.

Dengan demikian bahwa unsur pembelajaran keterampilan motorik sebagai bagian dari proses pendidikan punya peran sangat signifikan untuk mencapai tujuan pendidikan, 
JURNAL SPORTA SAINTIKA

P-ISSN 2505-5651

E-ISSN 2579-5910

yaitu terbentuknya manusia yang berwawasan luas, mandiri, bijak, peduli sosial, terampil, dan profesional (Prastowo, 2016: 203). Keterampilan motorik tidak berkembang secara ajaib dari satu hari ke hari berikutnya. Mereka harus diajarkan dan dipraktikkan (Clark, 2007: 39). Manusia yang terampil mengembangkan unsur keterampilan motoriknya sesuai bakat dan potensi yang dimiliki diharapkan dapat membawa bangsa dan negara menuju kehidupan yang semakin baik, maju, dan sejahtera. Bagi manusia yang terampil mengaplikasikan keterampilan motoriknya dalam kehidupan akan berguna dan bermakna, bukan hanya bagi diri sendiri melainkan juga bagi orang lain, bangsa, dan negara.

Kemampuan dan keterampilan motorik merupakan sisi penting kehidupan karena dari sinilah manusia dapat mengekspresikan dan mengaktualisasikan potensi, bakat, kelebihan, dan talentanya (Kurdi \& Sukadiyanto, 2014: 169). Pembelajaran keterampilan motorik yang digelar di berbagai lembaga pendidikan merupakan bagian penting dari upaya membentuk karakter, moralitas, dan sikap sosial yang menjadi salah satu unsur utama untuk membangun bangsa dan negara menuju hari depan yang lebih baik dan semakin baik. Untuk mengembangkan dan menyalurkan bakat dan potensi yang dimiliki, seseorang hampir selalu melibatkan unsur geraknya, baik dalam intensitas yang sedikit, sedang, atau banyak. Komponen sistem saraf dan otot dalam tubuh bekerjasama untuk menggelar aktivitas keterampilan motorik yang bermanfaat dalam kehidupan manusia (Rahyubi, 2012: 207). Jika sistem saraf dan otot berpadu dengan baik, maka setidaknya seseorang telah merintis jalan untuk meraih kesuksesan dalam berbagai lapangan, pekerjaan, dan profesinya. Oleh karena itu tidak dapat dipungkiri bahwa pembelajaran keterampilan motorik merupakan hal yang sangat penting dalam kehidupan manusia..

\section{PEMBAHASAN}

\section{Hakikat Gerak}

Gerak adalah suatu pergantian posisi yang dilakukan oleh setiap orang. Gerak adalah sesuatu yang ditampilkan oleh manusia secara nyata dan dapat diamati. Lebih lanjut dikatakan bahwa gerak ibarat pupuk makanan bagi pertumbuhan dan perkembangan. Gerak atau juga dikenal dengan motorik terjadi akibat adanya koordinasi antara organ-organ pada tubuh. Pada manusia gerak terjadi melalui rangsangan yang diterima saraf yang dikirim ke otak dan otak memerintahkan pada otot untuk bergerak (Komaini, 2018: 18).

Gerak adalah proses perpindahan dari satu tempat ke tempat lain untuk mencapai tujuan yang memerlukan waktu yang dinamis. Gerak tidak bersifat materiil tetapi merupakan suatu bagan atau skema yang dapat dimengerti oleh akal budi kita. Gerak manusia adalah suatu proses yang melibatkan sebagian atau seluruh bagian tubuh dalam satu kesatuan 
JURNAL SPORTA SAINTIKA

P-ISSN 2505-5651

E-ISSN 2579-5910

yang menghasilkan suatu gerak statis ditempat dan dinamis berpindah tempat (Widati et al., 2010:1).

Kemampuan motorik merupakan hasil gerak individu dalam melakukan gerak, baik gerak yang bukan gerak olahraga maupun gerak dalam olahraga atau kematangan penampilan keterampilan motorik. kemampuan merupakan ciri umum atau kapasitas individu yang merupakan penentu potensi pencapaian seseorang untuk unjuk kerja keterampilan tertentu, sehingga kemampuan motorik asalah suatu kemampuan yang secara khusus terkait dengan kinerja keterampilan motorik atau gerak yang dilakukan oleh individu (Magill \& Anderson, 2016: 53).

Kemampuan gerak adalah suatu kemampuan seseorang dalam menampilkan keterampilan gerak yang lebih luas serta diperjelas bahwa kemampuan motorik suatu kemampuan umum yang berkaitan dengan penampilan berbagai keterampilan atau tugas gerak (Sukadiyanto, 1997: 70). Kemampuan gerak motorik merupakan suatu kemampuan umum seseorang yang berkaitan dengan penampilan tugas gerak.

Kemampuan motorik adalah kapasitas seseorang yang berkaitan dengan pelaksanaan dan peragaan suatu keterampilan yang dipelajari, sehingga akan memberi dampak pada pertumbuhan dan perkembangan anak. Kemampuan motorik lebih tepat merupakan kapasitas yang berkaitan dengan pelaksanaan dan peragaan keterampilan yang relatif melekat pada anak. Faktor biologis, fisik, kesehatan, gizi dianggap sebagai kekuatan utama yang berpangaruh terhadap motorik dasar seseorang. Motorik dasar itulah yang kemudian berperan sebagai landasan bagi perkembangan keterampilan (Lutan, 2001: 8). Gerak (motor) sebagai istilah umum untuk berbagai bentuk perilaku gerak manusia. Psikomotor khusus digunakan pada domain mengenai perkembangan manusia yang mencakup gerak manusia (Ma'mun \& Saputra, 2000: 20). Jadi gerak (motor) ruang lingkupnya lebih luas dari pada psikomotorik. Psikomotorik mengacu pada gerakan-gerakan yang dinamakan alih getaran elektrolit dari pusat otot besar.

Proses terjadinya gerakan pada manusia dimulai dari adanya stimulus (S) yang diterima oleh reseptor $(\mathrm{R})$ yang terdiri dari panca indera. Dibawa oleh syaraf-syaraf sensorik menuju ke otak (O). Stimulus tersebut diolah di otak, lalu memberikan balikan melalui syaraf motorik ke alat-alat gerak (efektor/E) seperti otot, tulang dan sendi. Sehingga manusia dapat bergerak (Widati et al., 2010: 1).

Beberapa pendapat di atas yang dimaksud kemampuan motorik adalah suatu kemampuan yang dapat diperoleh dari keterampilan gerak yang berkaitan dengan pelaksanaan dan peragaan suatu keterampilan yang dipelajari sehingga nantinya akan 
JURNAL SPORTA SAINTIKA

P-ISSN 2505-5651

E-ISSN 2579-5910

memberikan dampak bagi pertumbuhan dan perkembangan anak tersebut.

\section{Keterampilan Motorik}

Keterampilan motorik merupakan sebuah proses di mana seseorang mengembangkan seperangkat respons ke dalam suatu gerak yang terkoordinasi, terorganisasi, dan terpadu. (Lutan, 1988: 95). Ciri-ciri gerak seseorang dikatakan terampil ditandai dengan kemampuan untuk menghasilkan sesuatu dalam kualitas tinggi (seperti cepat atau cermat) dengan tingkat keajegan yang cukup mantap (Lutan, 1988: 95). Keterampilan motorik digunakan untuk menunjukkan setiap aktivitas otot yang diarahkan kepada suatu tujuan khusus (Rahantoknam, 1988: 13). Keterampilan motorik yaitu kemampuan sesorang untuk melakukan tugas gerak secara maksimal sesuai dengan kemampuannya (Rahayubi, 2012:211). Keterampilan motorik merupakan kesadaran individu untuk mengontrol tubuh bergerak atau melakukan tugas sesuai dengan tujuan yang dicapai (Kluka, 1999: 5).

Jadi dari uraian yang telah dikemukakan keterampilan motorik adalah suatu gerakan yang terampil yaitu derajat keberhasilan yang konsisten dalam mencapai suatu tujuan yang efektif dan efisien akibat dari perpaduan kerja sama sistem saraf dan otot.

Hal penting dalam mempelajari keterampilan motorik (Sukamti, 2007: 2-3) antara lain: (1) kesiapan belajar, (2) kesempatan belajar, (3) kesempatan berpraktek, (4) model yang baik, (5) bimbingan, (6) motivasi, (7) setiap keterampilan motorik harus dipelajari secara individ, (8) keterampilan sebaiknya dipelajari satu demi satu. Cara umum mempelajari keterampilan motorik antara lain: (1) belajar coba dan galat (trial and error), (2) meniru, (3) pelatihan.

\section{Belajar Motorik}

Belajar motorik adalah suatu proses perubahan yang relatif permanen dalam perilaku gerak yang dihasilkan dari praktik atau pengalaman masa lalu (Gallahue et al., 2012: 14). Belajar motorik adalah upaya untuk memperoleh keterampilan motorik, peningkatan kinerja yang dipelajari dengan latihan, pengalaman, perolehan kembali keterampilan yang sulit dilakukan atau tidak dapat dilakukan. Keterampilan motorik merupakan aktivitas atau tugas yang memerlukan kontrol atas gerakan sendi dan segmen tubuh untuk mencapai suatu tujuan kualitas gerak (Magill \& Anderson, 2016: 3). pembelajaran motorik adalah serangkaian proses yang terkait dengan praktik atau pengalaman yang mengarah pada perubahan yang relatif permanen dalam kemampuan gerakan terampil, yang meliputi: (1) belajar adalah proses memperoleh kemampuan untuk menghasilkan tindakan terampil, (2) pembelajaran terjadi sebagai akibat langsung dari praktik atau pengalaman, (3) 
JURNAL SPORTA SAINTIKA

P-ISSN 2505-5651

E-ISSN 2579-5910

pembelajaran tidak dapat diamati secara langsung karena perubahan bersifat internal, (4) pembelajaran menghasilkan perubahan yang relatif permanen dalam kemampuan perilaku terampil (Schmidt et al., 2019: 410). Belajar motorik merupakan kendali optimal, ditambah dengan estimasi keadaan, menyediakan kerangka kerja yang kuat untuk menggambarkan koordinasi dalam tugas-tugas yang dipelajari secara berlebihan, gerakan membutuhkan latihan ekstensif sebelum mencapai kemahiran apa pun, kapasitas untuk mempelajari pola gerakan baru dan meningkatkan serta menyesuaikan pola yang sudah ada dapat dibilang merupakan aspek yang paling fundamental dari sistem motorik manusia (Gollhofer et al., 2012: 19-20). Pembelajaran motorik adalah subdisiplin perilaku motorik yang meneliti bagaimana orang memperoleh keterampilan motorik dengan perubahan yang relatif permanen dalam kemampuan menjalankan keterampilan motorik sebagai hasil dari latihan atau pengalaman (Haibach-Beach et al., 2018: 37). Selain itu belajar motorik merupakan studi tentang keterampilan untuk memperoleh dan menyempurnakan gerakan. Belajar motorik sangat dipengaruhi oleh berbagai bentuk latihan, pengalaman, dan situasi belajar manusia. Untuk dapat melakukannya diperlukan adanya kontrol perhatian (atensi), dan pemusatan perhatian atau konsentrasi (Rahayubi, 2012:207).

\section{Mekanisme Pergerakan}

Pada manusia pergerakan motorik dimungkinkan karena adanya sistem otot yang melekat pada tulang dan saraf-saraf yang menginervasmya. Terlaksanaanya kegiatan motorik yang sempurna akibat adanya komponen-komponen yang bekerja sama. Komponen tersebut meliputi gerakan dan energi, koordmasi, keseimbangan refleks, tonus otot, dan asosiasi (Sumarmo, 1982: 34). Fungsi utama saraf menerima rangsang, mengirim rangsang dari satu tempat ke tempat lam dan selanjutnya mengadakan reaksi sebagai jawaban atas rangsang tersebut (Soejanto, 1987: 86). Gerakan motorik atas rangka dapat diatur dari berbagai tingkatan di dalam sistem saraf pusat yang meliputi: (a) medulla spinalis; (b) subtansi retikularis medulla oblongata pons dan mesensefalon; (c) ganglia basalis; (d) cerebelum, dan (e) korteks motorik (Hall \& Hall, 2020: 569). Tiap-tiap tingkatan mempunyai peran khusus dalam mengatur gerakan motorik, tingkatan yang lebih rendah terutama pentmg untuk gerakan refleks terhadap jawaban rangsang sedangkan pada tingkatan yang lebih tmggi terutama untuk gerakan yang sengaja diatur dalam proses berpikir.

\section{Tahap-Tahap Belajar Motorik}

Tahap belajar motorik ada tiga tahapan yaitu (1) kognitif atau formasi rencana, (2) asosiatif atau latihan, dan (3) otomatisasi (Hariyanto \& Mustafa, 2020: 187). Berikut ini adalah penjelasan dari masing-masing tahap belajar motorik. 
JURNAL SPORTA SAINTIKA

P-ISSN 2505-5651

E-ISSN 2579-5910

Tahap kognitif atau formasi rencana merupakan tahap dimana seseorang sedang menerima rangsangan pada alat-alat reseptor sebagai masukan bagi sistem memorinya (Hariyanto \& Mustafa, 2020: 188). Tahap kognitif merupakan tahap awal dalam belajar motorik, pada tahap ini siswa berusaha memahami bentuk-bentuk gerakan yang dipelajari, keterampilan intelektual banyak dilibatkan pada tahap ini. Siswa mulai mencoba-coba dalam melaksanakan tugas motorik (Winarno, 1995: 12). Dalam tahap kognitif yang perlu diperhatikan mencakup: (1) Kapasitas dan keterbatasan reseptor (ketajaman sensori, spesifikasi penemuan, doktrin yang masuk lebih dulu, menemukan kewaspadaan), (2) Kemampuan dan keterbatasan persepsi manusia (Rahantoknam, 1988: 157-160).

Tahap asosiatif atau latihan yaitu dimana pola gerak yang telah terbentuk dalam sistem memori sedang diunjuk kerjakan. Unjuk kerja keterampilan pada awalnya dilakukan dengan tingkat koordinasi yang rendah (Hariyanto \& Mustafa, 2020: 189). Pada tahap ini menekankan penyempurnaan pola gerakan (Lutan, 1988: 320). Tahap asosiatif adalah tahap kedua dalam belajar motorik. Pada tahap ini asosiasi verbal mulai ditinggalkan, dan si pelaku memusatkan perhatian pada bagaimana melakukan pola motorik yang baik (benar). Permulaan dari tahap ini ditandai oleh semakin efektifnya cara-cara siswa melaksanakan tugas motorik, dan mereka mulai mampu menyesuaikan diri dengan keterampilan yang dilakukan (Winarno, 1995: 12-13). Dalam tahap asosiatif juga disebut tahap fiksasi yang perlu diperhatikan mencakup: (1) Isyarat-isyarat reseptor dalam latihan, (2) Jadwal dan distribusi latihan, (3) Belajar keseluruhan dan bagian, (4) Pengolahan dan balikan yang bersinambung (Rahantoknam, 1988: 166-171).

Tahap otomatisasi yakni dapat terjadi karena terjadinya hubungan yang permanen antara reseptor dengan efektor. Gerakkan otomatisasi dalam mekanismenya tidak lagi dikoordinasikan oleh sistem saraf pusat melainkan pada jalur singkat pada sistem saraf otonom (Hariyanto \& Mustafa, 2020: 190). Pada tahap ini hampir-hampir tak membutuhkan perhatian dalam pelaksanaannya (Lutan, 1988: 320). Tahap otomatisasi merupakan tahap paling akhir dari belajar motorik. Pada pelaksanaan otomatis, siswa yang belajar keterampilan makin ringan dalam penyelesaian tugas keterampilan, dan ini berarti makin menurun stres yang dialami oleh siswa (Winarno, 1995: 13). Dalam tahap otomatisasi yang perlu diperhatikan mencakup: (1) merubah rangkaian organisasi, (2) strategi baru untuk pola lama (Rahantoknam, 1988: 174-176).

Kurva belajar atau sering disebut kurva penampilan gerak ialah grafik yang melukiskan perkembangan dari rangkaian penampilan seseorang dalam suatu periode waktu usaha mencoba melaksanakan tugas gerak (Lutan, 1988: 119). Kurva belajar mengandung 
JURNAL SPORTA SAINTIKA

P-ISSN 2505-5651

E-ISSN 2579-5910

nilai praktis untuk memahami gejala belajar. Bentuk umum dari kurva belajar adalah: (1) tahap awal ditandai dengan kemajuan pesat, terlukis dalam garis menanjak, (2) fase plateau, kemajuan lamban atau mendatar, bahkan diikuti oleh irama kemajuan tak menentu naik turun; dan (3) tahap penurunan yang terlukis pada garis menurun.

Motor educability merupakan istilah yang menunjukkan kapasitas seseorang mempelajari keterampilan yang sifatnya baru daiam waktu yang cepat dengan kualitas yang baik. Motor educability dianggap sebagai indikator inteligensi dalam belajar motorik (Lutan, 1988: 119).

Dari uraian di atas maka dapat disimpulkan belajar motorik adalah serangkaian proses yang berkaitan dengan latihan atau pembekalan pengalaman yang akan menyebabkan perubahan dalam kemampuan individu untuk bisa menampilkan gerak yang terampil.

\section{Sistem Piramidal dan Ekstrapiramidal pada Gerakan}

\section{Sistem Piramidal}

Sistem piramidal atau biasa yang disebut traktus kortikospinalis merupakan jalur neuron tunggal yang keluar dari kortek serebri menuju ke medula spinalis tanpa membentuk sinaps. Fungsi utama dari sistem ini adalah untuk melakukan gerakan volunter dan gerakan terampil dibawah kontrol kesadaran. Sistem piramidal membawa input dari area motorik primer, area premotor, areamotorik tambahan. Impuls yang dimunculkan oleh kortek motorik berasal dari impuls yang diterima dari kortek sensorik yang menerima stimulus astu rangsang yang diterima oleh sarafsensorik yang berada di perifer. Serabut saraf piramidalis menyilang ke sisi yang berlawanan pada medula oblongata. Pada sistem piramidal terdapat 2 macam neurotransmitter yang berperan penting, yakni neurotransmitter glutamate yang berfungsi sebagai eksitasi dan neurotransmitter gamma-aminobutyric acid (GABA) yang berfungsi sebagai inhibitor (Levitt, 2013: 37).

Lesi traktus piramidal ditandai dengan (1) adanya tanda babinski yang ditandai dengan dorso fleksi ibu jari kaki dan jari lainnya bergerak keluar ketika kulit telapak kaki sepanjang sisi lateral digores, (2) hilangnya reflek abdominalis superfisial otot abdominal gagal berkontraksi otot-otot kremaster gagal berkontraksi ketika kulit pada sisi medial paha digores, (3) hilangnya penampakan gerakan-gerakan volunter terlatih yang halus terutama terjadi pada ujung-ujung distal anggota gerak (Dorlan, 2009: 159).

\section{Sistem Ekstrapiramidal}

Komponen dari sistem ekstrapiramidal adalah jalur desenden brain stem. Jalur desenden brain stem dikelompokkan menjadi dua grup fungsional, yakni 
JURNAL SPORTA SAINTIKA

P-ISSN 2505-5651

E-ISSN 2579-5910

jalur medial dan lateral. Jalur medial berfungsi untuk mengontrol postur, pola sinergis ekstensor pada seluruh ekstermitas dan gerakan orientasi dari kepala dan badan. Jalur mempunyai kapasitas untuk gerakan fleksor yang independen khususnya pada lengan (Rosenbaum et al., 2007: 10).

Jalur desenden brain stem medial meliputi medullary retikulospinal, vestibulospinal, dan tektospinal. Medullary retikulospinal berasal dari neuron di formasio retikularis. Aktivitas pada bagian ini adalah inhibisi dari ekstensor motor neuron, eksitasi fleksor motor neuron dan menginhibisi tendon reflek. Vestibulospinal berasal dari nukleus vestibularis. Nukleus vestibularis merupakan sumber dari kebanyakan proyeksi vestibular ke spinal motor neuron. Nukleus ini menerima input aferen dari saraf vestibularis dan input lain dari serebelum. Aktivitas pada nukleus ini memproduksi eksitasi ekstensor motor neuron. Traktus vestibulospinal yang berasal dari nukleus vetibular lateralis tidak turun menyilang di ventral funikulus medulla spinalis. Serabut saraf ini berakbir di bagian anterior hom cell (AHC) pada. alpha motor neuron dan gamma motor neuron. Sedangkan traktus tektospinal penting untuk mediasi gerakan retlek kepala terhadap stimulus visual dan audio (Rosenbaum et al., 2007: 10).

Jalur desenden brain stem sisi lateral meliputi traktus rubrospinal yang berasal dari red nucleus, dan traktus pontin retikulospinal yang berasal dari dorsolateral formasio pontin reticular. Aktivitas pada bagian formasio retikularis memproduksi eksitasi ekstensor motor neuron dan menginhibisi fleksor motor neuron (Rosenbaum et al., 2007: 10).

Secara umum respon gamma motor neuron terhadap stimulus sama dengan alpha motor neuron yang menginervasi otot-otot ekstensor yang dieksitasi oleh traktus vestibulospinal dan traktus pontin retikulospinal. Gamma motor neuron mempunyai threshold yang lebih rendah dibanding alpha motor neuron. Sehingga stimulus yang tidak mampu mengeksitasi alpha motor neuron, mampu mengeksitasi gamma motor neuron dan stimulus yang mampu mengeksitasi alpha motor neuron mungkin akan membuat eksitasi gamma motor neuron yang berlebihan (Rosenbaum et al., 2007: 11).

\section{Peran Pendidikan Jasmani dalam Membentuk Keterampilan Motorik}

Gerak adalah ciri kehidupan serta memelihara gerak adalah mempertahankan hidup dan meningkatkan kemampuan gerak adalah meningkatkan kualitas hidup. Dimensi gerak yang dimaksud adalah keterampilan motorik. Dalam kurikulum satuan pendidikan dasar dan menengah pembelajaran keterampilan motorik salah satunya terdapat dalam ruang lingkup PJOK namun mata pelajaran PJOK sering diabaikan dianggap mengganggu. Padahal keaktifan gerak sangat berpengaruh dalam kehidupan manusia agar terhindar dari resiko 
JURNAL SPORTA SAINTIKA

P-ISSN 2505-5651

E-ISSN 2579-5910

penyakit degeratif (Tarigan, 2011: 19). Selain itu keterampilan motorik berguna bagi kehidupan dan karier seseorang di berbagai lapangan kehidupan yang sesuai dengan bakat, minat, dan potensi (Rahayubi, 2012:211). Selain itu apabila peserta didik yang meninggalkan sekolah tanpa dasar keterampilan motorik yang kuat (tertinggal) mereka sama seperti pergi tanpa kemampuan bahasa atau matematika serta berdampak dalam belajar keterampilan baru juga akan tertinggal. Jadi perlu dibahas dan dikaji mendalam tentang pembelajaran keterampilan motorik agar dapat mencapai suatu tujuan yang baik dalam kehidupan individu.

Dalam pembelajaran PJOK metode gabungan, yaitu kombinasi dalam bagian yang hampir sama dengan metode langsung dan tidak langsung, meningkatkan keterampilan motorik lebih banyak daripada metode lainnya yang meliputi metode langsung, tidak langsung, dan bermain. Metode langsung yaitu guru sebagai pusat pembelajaran gerak yang memberikan stimulus, sedangkan yang dimaksud metode tidak langsung yaitu siswa sebagai pusat pembelajaran gerak (Emmanouel et al., 1992: 1164). Jadi dengan kata lain metode langsung dapat dikatakan pendekatan stimulus respon dan metode tidak langsung disebut kognitif (Lutan, 1988: 142-143). Bedasarkan jenis karakteristiknya secara umum keterampilam motorik yang berada dalam pendidikan jasmani di jenjang sekolah terdiri dari tingkat pra sekolah, sekolah dasar, sekolah menengah pertama, dan sekolah menengah atas.

\section{Keterampilan Motorik Usia Pra Sekolah}

Perkembangan motorik anak pada usia ini mengalami kemajuan yang besar terhadap keterampilan motorik kasar dibanding keterampilan motorik halus. Keterampilan motorik kasar seperti berlari, melompat, atau aktivitas sejenis lainnya yang melibatkan otot besar. Adanya peningkatan otot dan tulang yang semakin kuat serta perkembangan paru-paru yang semakin membaik dan membesar, memungkinkan mereka untuk berlari, memanjat, dan melompat lebih baik, lebih cepat, dan lebih jauh dari keadaan sebelumnya. Ketika berusia 34 tahun, anak-anak sangat gemar melakukan kegiatan di atas. Mereka melakukan hal-hal tersebut hanya untuk menyenangkan hati serta ingin menunjukkan atau membanggakan bahwa mereka memiliki kemampuan yang mereka rasa sangat istimewa di masa itu. Ketika anak-anak mencapai usia 5 tahun, mereka semakin berani melakukan aktivitas yang terkadang berbahaya untuk usia mereka dan mendebarkan jantung orang dewasa. Anak yang berusia 5 tahun mampu berlari dengan kencang dan gemar berlomba dengan kawankawan sebaya maupun orangtua (Santrock, 2012: 242).

Dalam usia pra sekolah keterampilan motorik berperan untuk perkembangan perseptual, sosial, dan kognitif, sebab kontribusi sistem motorik yang sehat berfungsi baik 
JURNAL SPORTA SAINTIKA

P-ISSN 2505-5651

E-ISSN 2579-5910

untuk pembelajaran anak-anak. Akibatnya, nampak jelas bahwa perkembangan motorik sangat penting untuk pemahaman anak-anak tentang dunia fisik dan sosial (Libertus \& Hauf, 2017: 1-3). Selain itu perkembangan motorik balita, anak-anak prasekolah, dan anak-anak di kelas dasar awal yang terdiri dari berlari, melompat, mencongklang, melompat, menendang, melempar, dan menangkap hendaknya diperlukan sebelum anak-anak berusia delapan atau 10 tahun (Clark, 2007: 39).

\section{Keterampilan Motorik Usia Sekolah Dasar}

Perkembangan motorik usia sekolah dasar lebih halus dan lebih terkoordinasi dibanding dengan usia di masa kanak-kanak awal. Karena perkembangan otak pada masa kanak-kanak ditandai dengan pertumbuhan struktur, khususnya lobus frontal. Lobus ini terletak di bagian depan otak bawah tengkorak yang berfungsi antara lain untuk perencanaan, penalaran, penilaian sosial, etika, dan pengambilan keputusan. Perkembangan keterampilan motorik merupakan kemampuan berperilaku atau kemampuan bergerak motorik. Keterampilan motorik tersebut terbagi menjadi dua yakni keterampilan motorik kasar (gross motor skills) yang melibatkan penggunaan gerakan tubuh yang besar dan keterampilan motorik halus (soft motor skills) yang melibatkan penggunaan gerakan tubuh kecil. Pada usia ini, anak-anak sangat suka berlari, melompat, melempar, memanjat, menangkap, dan lain sebagainya. Oleh karena itu, selama masa kanak-kanak tengah, anakanak menjadi lebih mahir dalam kegiatan motorik kasar (Danim, 2011: 62). Sedangkan bagi anak-anak yang memainkan alat-alat musik seperti piano, suling, atau instrumen lainnya akan mengembangkan keterampilan motorik halusnya. Sebenarnya, pengembangan keterampilan motorik halus berjalan seiring dengan pertumbuhan fisik anak-anak. Keterampilan motorik halus pada anak perempuan biasanya lebih unggul dibandingkan pada anak laki-laki (Santrock, 2011: 320).

Keterampilan motorik dalam pendidikan dasar, tidak ada perbedaan penting antara anak laki-laki dan anak perempuan, namun beberapa fitur perlu dipertimbangkan untuk meningkatkan kinerja. Fitur-fitur ini berkaitan dengan kematangan gerakan, ekonomis, fluiditas, tempo, dan ekspresivitasnya. Anak laki-laki memiliki kecenderungan terhadap latihan kekuatan, kadang-kadang kecepatan, mengalahkan lawan, dengan bimbingan yang tepat dapat meningkatkan efisiensi, sementara anak perempuan lebih menyukai gerakan ekspresif, dilakukan pada musik, sering ditandai dengan kurangnya ekonomis, namun cenderung keakuratan teknis (Mihaela \& Laurentiu-Gabriel, 2014: 751). Hasil tersebut tidak dapat dicapai jika guru gagal menggabungkan strategi pengajaran (metode seleksi, sarana, bentuk organisasi dan bahan ajar yang tersedia) dengan tingkat kebugaran fisik dan 
JURNAL SPORTA SAINTIKA

P-ISSN 2505-5651

E-ISSN 2579-5910

keterampilan yang terkait dengan peserta didik.

Kemampuan motorik anak usia sekolah semakin terkoordinasi sehingga mereka bisa mengendalikan gerakan mereka dengan ketangkasan yang jauh lebih besar daripada sebelumnya. Keterlibatan dalam semua jenis kegiatan kurikuler dan ekstrakurikuler membantu mereka menyempurnakan keterampilan psikomotor mereka. Pertumbuhan fisik selama fase ini sangat bervariasi, dengan tingkat perkembangan yang berbeda dari anak ke anak. Menjelang akhir masa perkembangan ini, anak perempuan lebih besar daripada anak laki-laki pada rata-rata mulai mengalami perubahan tubuh secara prematur dan cenderung melampaui anak laki-laki dalam pematangan fisik (Bastable \& Dart, 2007: 183).

Keterampilan motorik dasar diasumsikan memegang posisi kunci dalam rangkaian pendidikan gerakan untuk anak usia sekolah dasar. Misalnya, penguasaan keterampilan motorik dasar dianggap sebagai pendahulu penerapannya dalam konteks olahraga tertentu, dan sebaliknya, kurangnya kemampuan dipuji sebagai alasan utama terjadinya gesekan olahraga terorganisir (Miller, 2006: 1).

\section{Keterampilan Motorik Usia Sekolah Menengah Pertama}

Perubahan dalam penampilan gerak pada masa remaja mengikuti perubahan perubahan dalam ukuran badan,kekuatan dan fungsi fisiologis. Anak laki-laki mengalami peningkatan yang signifikan tetapi anak perempuan tidak menunjukan peningkatan yang berarti ,bahkan menurun pada umur menstruasi hal tersebut dapat dilihat dari gerakan lari lompat jauh tanpa awalan dan melempar jarak jauh, karena anak perempuan mencapai hasil maksimal dalam berlari pada usia 13 tahun dan menunjukkan sedikit perubahan dalam melempar dan melompat sesudah umur tersebut. Hal tersebut disebabkan oleh kemampuan yang terdapat dalam keterampilan fisik yang terdiri dari kekuatan, kecepatan, keseimbangan, koordinasi, dan kelincahan yang juga unsur dari kemampuan motorik (Muthohir \& Gusril (2004:50).

Pertumbuhan yang cepat pada laki-laki memberikan keuntungan dalam ukuran dan bentuk tubuh, kekuatan dan fungsi fisiologis yang memberikan kemudahan dalam penampilan fisik selama masa remaja. Peningakatan koordinasi pada anak laki-laki terus berjalan dengan berjalannya umur kronologis,sedangkan anak perempuan sudah tidak berkembang lagi sesudah umur 14 tahun kelincahan anak laki-laki lebih unggul dibanding perempuan kelincahan anak wanita dewasa kurang baik daripada kelincahan wanita masih muda atau anak-anak tetapi wanita dewasa lebih bisa menjaga posisinya.

Masa sebelum remaja dan remaja merupakan saat peningkatan penampilan gerak seperti lari cepat, lari jarak jauh, dan lompat tinggi. Peningkatan secara kuantitatif yang 
JURNAL SPORTA SAINTIKA

P-ISSN 2505-5651

E-ISSN 2579-5910

berlangsung terus akan mengahasilkan peningkatan penampilan dan daya tahan. Pernyataan tersebut selaras dengan pendapat dari Rahayubi (2012:225) faktor yang mempengaruhi perkembangan motorik meliputi: perkembangan sistem saraf, kondisi fisik, motivasi, lingkungan, psikologis, usia, jenis kelamin, serta bakat dan potensi. Demikian ini pula sumbangan diri unsur koordinasi tidak diragukan lagi dalam menunjang peningkatan keterampilan.

Keterampilan gerak pada masa remaja sangat dipengaruhi oleh penguasaan gerak dasar pada masa anak-anak dan oleh faktor latihan (Mustafa et al., 2016: 173). Oleh karena itu kecenderungan keterampilan setiap individu pada masa remaja semakin bervariasi ada keterampilan yang berkembang dengan baik ada pula yang tidak baik.

\section{Keterampilan Motorik Usia Sekolah Menengah Atas}

Perkembangan pertumbuhan yang stabil dan lambat terjadi pada kelompok usia ini. Remaja akhir secara bertahap mengambil kendali atas kemampuan motorik halus dan kasar, misalnya siswa menjadi lebih mahir dalam seni (penanganan kuas cat) dan Pendidikan jasmani (menggiring bola basket). Anak-anak di kelompok usia mulai menunjukkan sifat fisik orang dewasa. Tubuh dan pikiran mulai bekerja sama (Wardell, 2007: 2).

Pendidikan Jasmani di SMA mengenai kemampuan gerak menyiratkan pengembangan kemampuan yang memadai untuk menikmati partisipasi dalam aktivitas fisik, yang akan memfasilitasi perolehan keterampilan motorik lanjutan dan peningkatan kemampuan untuk terlibat dalam pola motorik yang sesuai dalam aktivitas fisik sehari-hari, aktivitas fisik, dan olahraga seumur hidup (Bert, 2015: 52).

Jadi dengan demikian tingkatan keterampilan motorik pada siswa SMA sudah dapat dibentuk spesifikasi atau spesialisasi dalam olahraga, atau dapat melakukan gerakan lanjutan yang lebih kompleks.

\section{Peran Keterampilan Motorik dalam Hidup}

Peran keterampilan motorik sangat penting dalam kehidupan, sebab pada hakikatnya hidup memerlukan gerak. Agar gerak dapat efektif dan efisien maka pergerakan harus terampil yaitu energi yang digunakan lebih ekonomis namun dapat menghasilkan gerakan yang terampil. Dalam sistem gerak, beberapa area di otak saling bekerjasama untuk menghasilkan gerakan yang halus terkoordinasi. Gerakan yang terampil dan terkoordinasi dihasilkan dari kerja kortek motorik yang dibantu oleh basal ganglia (Gordon, 2005: 30). Sebuah perencanaan motorik dibuat oleh area premotor yang nantinya akan dieksekusi oleh area motorik primer. Gerakan yang dihasilkan oleh kortek motorik primer masih kasar, sehingga perlu dikontrol oleh area premotor yang berhubungan dengan basal ganglia. 
JURNAL SPORTA SAINTIKA

P-ISSN 2505-5651

E-ISSN 2579-5910

Dengan peran dari basal ganglia maka gerakan yang dihasilkan akan lebih terkontrol.

Selain itu dalam kehidupan psikososial juga berhubungan dengan keterampilan motorik, sebab dengan memiliki keterampilan motorik yang baik dapat meningkatkan kesejahteraan emosional (Mancini et al., 2018: 1). Psikososial adalah suatu kondisi yang terjadi pada individu yang mencakup aspek psikis dan sosial atau sebaliknya. Psikososial menunjuk pada hubungan yang dinamis antara faktor psikis dan sosial, yang saling berinteraksi dan memengaruhi satu sama lain. Psikososial sendiri berasal dari kata psiko dan sosial. Kata psiko mengacu pada aspek psikologis dari individu (pikiran, perasaan dan perilaku) sedangkan sosial mengacu pada hubungan eksternal individu dengan orang-orang di sekitarnya (Chaplin, 2011: 165). Apabila dihubungkan dengan keterampilan motorik dalam Pendidikan Jasmani yaitu pendidikan melalui gerak yang dapat dilakukan dengan bermain atau pun melawan kondisi fisik dari diri sendiri. Penanaman disiplin, jujur, tanggung jawab, dan kerjasama lebih mudah dilakukan dan dibentuk melalui kegiatan bermain, bukan disajikan secara teoritik (Winarno, 2012: 6). Sebab dengan bermain seseorang akan kelihatan karakternya, apakah dia disiplin, jujur, tanggung jawab, dan kerjasama atau tidak. Kerja sama akan lebih mudah dilakukan melalui permainan beregu, seperti sepakbola. Sedangkan percaya diri dan kemandirian peserta didik akan dapat dibentuk melalui olahraga perorangan, seperti pencak silat, karate, tinju, dan sebagainya. Kesabaran, tanggung jawab, percaya diri dapat juga dilakukan melalui pendidikan seni (esthetics). Dengan demikian dapat dikatakan bahwa peran keterampilan motorik dari segi psikososial sangat signifikan, sebab dapat membentuk karakter dan interaksi sosial yang baik. Selanjutnya keterampilan motorik juga dapat dengan memiliki daya ingat yang baik dengan kata lain di usia tua masih memiliki daya memori yang lebih kuat daripada orang yang tidak memiliki keterampilan motorik (Voelcker-Rehage, 2008: 5).

Dalam belajar keterampilan otorik biasanya dengan diberikan stimulus. Dengan mengamati orang lain berlatih dan belajar tugas motorik meningkatkan perolehan keterampilan, yang mungkin diakibatkan oleh melibatkan pengamat dalam proses kognitif yang khas dari proses pembelajaran. Efek dari mengamati model pembelajaran, dan mendukung gagasan bahwa satu penyebab mendasar akselerasi akuisisi dan retensi ini adalah keterlibatan dalam proses kognitif yang menjadi ciri tahap awal keterampilan belajar (Hebert, 2018: 7). Secara khusus, pengamatan model pembelajaran memfasilitasi eksplorasi dan evaluasi kemungkinan pola koordinasi dan strategi menilai kelayakannya, dan mengidentifikasi kesalahan dan cara untuk menghentikannya (Hebert, 2018: 15). Selain itu demonstrasi dapat digantikan oleh video yang disesuaikan dengan tugas pemodelan (proses 
JURNAL SPORTA SAINTIKA

P-ISSN 2505-5651

E-ISSN 2579-5910

dimana pengamat mempelajari keterampilan motorik dengan mereproduksi tindakan yang ditunjukkan), namun hanya jika seseorang memiliki maksud eksplisit untuk menggunakan permainan tersebut untuk menghasilkan kemajuan dalam keterampilan sebenarnya (Fery \& Ponserre, 2001: 1027).

Pembelajaran keterampilan motorik dapat dilakukan dengan mengamati objek atau teknik dengan seksama sebelum melakukan gerakan pada diri sendiri. Namun dalam pembelajaran motorik seharusnya seorang pendidik juga memperhatikan gaya belajarnya antara verbal atau visual (Fuelscher et al., 2012: 3). Hendaknya pelatih mengidentifikasi bagaimana peserta didik lebih memilih gaya belajar yang disukai untuk belajar. Hal tersebut dapat membantu pelatih saat memperkenalkan keterampilan baru atau menyempurnakan yang telah ditetapkan, sehingga dapat meningkatkan dan mempercepat pembelajaran keterampilan motorik.

Pengetahuan sebelumnya meningkatkan pembelajaran gerakan dan melindungi terhadap penurunan konsentrasi memori dalam kaitannya dengan usia. Keterampilan motorik yang diperoleh melalui pengalaman sebelumnya tidak hanya membantu mempertahankan fungsi dalam domain yang terlatih dengan baik, namun juga memperbaiki konsolidasi aspek baru di domain selama penuaan. Hasil ini bisa menjadi dasar untuk menyatukan penelitian tentang peran skema memori dalam memori deklaratif dan prosedural (Müller et al., 2016: 11-12). Jadi dapat dikatakan jika di usia muda memiliki keterampilan motorik yang baik maka di usia tua dapat melindungi penurunan konsentrasi memori.

\section{KESIMPULAN}

Gerak merupakan perpindahan dari tempat satu ke tempat lain dengan tujuan tertentu secara dinamis. Komponen unsur dalam gerak pada manusia antara lain: kekuatan, kecepatan, keseimbangan, koordinasi, dan kelincahan. Keterampilan motorik adalah suatu gerakan yang terampil yaitu derajat keberhasilan yang konsisten dalam mencapai suatu tujuan yang efektif dan efisien akibat dari perpaduan kerja sama sistem saraf dan otot. Belajar motorik adalah serangkaian proses yang berkaitan dengan latihan atau pembekalan pengalaman yang akan menyebabkan perubahan dalam kemampuan individu untuk bisa menampilkan gerak yang terampil. Faktor-faktor yang mempengaruhi belajar motorik adalah faktor internal dan eksternal. Dalam belajar motorik tak lepas dari sistem saraf. Dampak dari memiliki keterampilan motorik kepada kehidupan dapat mencakup peningkatan kualitas fisiologi manusia khususnya neuromuskuler dan psikososial. Dari fisiologi lebih mengarah pada sistem gerak yaitu saraf dan otot yang saling berkordinasi dengan baik. Sedangkan dalam segi psikososial yaitu memiliki konsep diri misalnya pengendalian emosional, 
JURNAL SPORTA SAINTIKA

P-ISSN 2505-5651

E-ISSN 2579-5910

kepercayaan diri serta dari segi sosial misalnya dapat bekerjasama dengan satu tim apabila pembelajaran keterampilan motorik berbasis permainan.

\section{DAFTAR PUSTAKA}

Baharom, M., Hashim, A., \& Mansor, M. (2014). Gross Motor Development Level Of The Children Age 9 Years: A Case Study. International Journal for Innovation Education and Research, 2(11), 129-135. https://doi.org/https://doi.org/10.31686/ijier.vol2.iss11.274

Bastable, S. B., \& Dart, M. A. (2007). Developmental stages of the learner. In Nurse as educator: Principles of teaching and learning practice (hal. 147-198).

Bert, G. (2010). Teaching High School Physical Education According to National Standards: The 6 Verbs of Success - Demonstrate, Understand, Participate, Achieve, Exhibit and Value. Strategies, 23(4), 28-31. https://doi.org/10.1080/08924562.2010.10590883

Bert, G. (2015). Teaching and Assessing Manipulative Motor Skills in High School Physical Education. Strategies, 28(2), 52-55. https://doi.org/10.1080/08924562.2015.1002352

Chaplin, J. P. (2011). Kamus Lengkap Psikologi. Jakarta: Rajagrafindo Persada.

Clark, J. E. (2007). On the Problem of Motor Skill Development. Journal of Physical Education, Recreation \& Dance, 78(5), 39-44. https://doi.org/10.1080/07303084.2007.10598023

Danim, S. (2011). Perkembangan Peserta Didik. Bandung: Penerbit Alfabeta.

Dorlan. (2009). Sensory Development: Pediater Phys Therapy. London: Pearson.

Emmanouel, C., Zervas, Y., \& Vagenas, G. (1992). Effects of Four Physical Education Teaching Methods on Development of Motor Skill, Self-Concept, and Social Attitudes of Fifth-Grade Children. Perceptual and Motor Skills, 74(3_suppl), 1151-1167. https://doi.org/10.2466/pms.1992.74.3c.1151

Fery, Y.-A., \& Ponserre, S. (2001). Enhancing the control of force in putting by video game training. Ergonomics, 44(12), 1025-1037. https://doi.org/10.1080/00140130110084773

Fuelscher, I. T., Ball, K., \& MacMahon, C. (2012). Perspectives on Learning Styles in Motor and Sport Skills. Frontiers in Psychology, 3(MAR), 2-4. https://doi.org/10.3389/fpsyg.2012.00069

Gallahue, D. L., Ozmun, J. C., \& Goodway, J. D. (2012). Understanding Motor Development: Infants, Children, Adolescents, Adults (7 ed.). New York: The McGraw-Hill Companies, Inc.

Giriwijoyo, H. Y. S. S., \& Sidik, D. Z. (2013). Ilmu Faal Olahraga (Fisiologi Olahraga). Bandung: Remaja Rosdakarya.

Gollhofer, A., Taube, W., \& Nielsen, J. B. (2012). Routledge Handbook of Motor Control and Motor Learning-Routledge. London: Routledge.

Gordon, J. (2005). A top-down model for neurologic rehabilitation. In Linking Movement Science and Intervention (hal. 28-33). Salt Lake City, Utah: American Physical Therapy Association.

Haibach-Beach, P. S., Reid, G. W., \& Collier, D. H. (2018). Motor Learning and Development. United 
JURNAL SPORTA SAINTIKA

P-ISSN 2505-5651

E-ISSN 2579-5910

States: Human Kinetics.

Hall, J. E., \& Hall, M. E. (2020). Guyton and Hall Textbook of Medical Physiology (14 ed.). Philadelphia: Elsevier Health Sciences.

Hariyanto, E., \& Mustafa, P. S. (2020). Pengajaran Remedial dalam Pendidikan Jasmani. (Mashud, Ed.). Banjarmasin: Lambung Mangkurat University Press.

Hastuti, D. (2009). Stimulasi Psikososial pada Anak Kelompok Bermain di Kota Bogor dan Pengaruhnya pada Perkembangan Motorik, Kognitif, Sosial Emosi dan Moral/Karakter Anak. Jurnal IImu Keluarga dan Konsumen, 2(1), 41-56. https://doi.org/10.24156/jikk.2009.2.1.41

Hebert, E. (2018). The Effects of Observing a Learning Model (or Two) on Motor Skill Acquisition. Journal of Motor Learning and Development, 6(1), 4-17. https://doi.org/10.1123/jmld.2016-0037

Kluka, D. A. (1999). Motor Behavior from Learning to Performance. Englewood: Morton Publishing Company.

Komaini, A. (2018). Kemampuan Motorik Anak Usia Dini. Depok: Rajawali Pers.

Kurdi, \& Sukadiyanto. (2014). Model Pembelajaran Motorik dengan Pendekatan Bermain Menggunakan Agility Ladder untuk Anak Sekolah Dasar. Jurnal Keolahragaan, 2(2), 194-203. https://doi.org/10.21831/jk.v2i2.2625

Le Masurier, G., \& Corbin, C. B. (2006). Top 10 Reasons for Quality Physical Education. Journal of Physical Education, Recreation \& Dance, 77(6), 44-53. https://doi.org/10.1080/07303084.2006.10597894

Levitt, S. (2013). Treatment of Cerebral Palsy and Motor Delay. Singapore: Wiley-Blackwell.

Libertus, K., \& Hauf, P. (2017). Editorial: Motor Skills and Their Foundational Role for Perceptual, Social, and Cognitive Development. Frontiers in Psychology, 8(MAR), 6-9. https://doi.org/10.3389/fpsyg.2017.00301

Lutan, R. (1988). Belajar Keterampilan Motorik : Pengantar Teori dan Metode. Jakarta: P2LPTK.

Lutan, R. (1996). Hakikat dan Karakteristik Penjaskes. Jakarta: Depdikbud.

Lutan, R. (2001). Asas-Asas Pendidikan Jasmani: Pendekatan Pendidikan Gerak di Sekolah Dasar. Jakarta: Depdiknas.

Ma'mun, A., \& Saputra, Y. M. (2000). Perkembangan Gerak dan Belajar Gerak. Jakarta: Depdikbud.

Magill, R., \& Anderson, D. I. (2016). Motor Learning and Control: Concepts and Applications. Dubuque: McGraw-Hill Education.

Mancini, V. O., Rigoli, D., Roberts, L. D., Heritage, B., \& Piek, J. P. (2018). The relationship between motor skills and psychosocial factors in young children: A test of the elaborated environmental stress hypothesis. British Journal of Educational Psychology, 88(3), 363-379. https://doi.org/10.1111/bjep.12187

Mihaela, I. T., \& Laurentiu-Gabriel, T. (2014). Teaching Approach to Enhance Motor Skills for Students 
JURNAL SPORTA SAINTIKA

P-ISSN 2505-5651

E-ISSN 2579-5910

in Primary School. Procedia - Social and Behavioral Sciences, 152, 746-751. https://doi.org/10.1016/j.sbspro.2014.09.314

Miller, J. (2006). Primary School-Aged Children and Fundamental Motor. Skills -What is All The Fuss About? Adelaide: Australian Association.

Mitayani, Y., T, N. R., \& Nursetiawati, S. (2015). Hubungan Stimulasi Ibu Dengan Perkembangan Motorik Pada Anak Usia 2-3 Tahun (Toddler). JKKP (Jurnal Kesejahteraan Keluarga dan Pendidikan), 2(1), 59. https://doi.org/10.21009/JKKP.021.09

Müller, N. C. J., Genzel, L., Konrad, B. N., Pawlowski, M., Neville, D., Fernández, G., ... Dresler, M. (2016). Motor Skills Enhance Procedural Memory Formation and Protect against Age-Related Decline. PLOS ONE, 11(6), e0157770. https://doi.org/10.1371/journal.pone.0157770

Mustafa, P. S., \& Dwiyogo, W. D. (2020). Kurikulum Pendidikan Jasmani, Olahraga, dan Kesehatan di Indonesia Abad 21. Jurnal Riset Teknologi dan Inovasi Pendidikan (JARTIKA), 3(2), 422-438. https://doi.org/https://doi.org/10.36765/jartika.v3i2.268

Mustafa, P. S., \& Winarno, M. E. (2020). Pengembangan Buku Ajar Pengajaran Remedial dalam Pendidikan Jasmani untuk Mahasiswa S1 Pendidikan Jasmani Dan Kesehatan Universitas Negeri Malang. Multilateral: Jurnal Pendidikan Jasmani dan Olahraga, 19(1), 1-12. https://doi.org/10.20527/multilateral.v19i1.7629

Mustafa, P. S., Winarno, M. E., \& Asim. (2016). Pengembangan Variasi Latihan Service Atas untuk Peserta Ekstrakurikuler Bolavoli di SMK Negeri 4 Malang. Jurnal Pendidikan Jasmani, 26(1), 159-175. https://doi.org/http://dx.doi.org/10.17977/pj.v26i1.7740

Mustafa, P. S., Winarno, M. E., \& Supriyadi. (2019). Penilaian Pendidikan Jasmani, Olahraga, dan Kesehatan pada Sekolah Menengah Pertama Negeri Kota Malang. Jurnal Pendidikan: Teori, Penelitian, dan Pengembangan, 4(10), 1364-1379. https://doi.org/http://dx.doi.org/10.17977/jptpp.v4i10.12845

Prastowo, A. (2016). Implikasi Kinerja Otak Terhadap Pembelajaran Psikomotorik di SD/MI. AlBidayah: Jurnal Pendidikan Dasar Islam, 8(2), 195-212.

Rahantoknam, B. E. (1988). Belajar Motorik: Teori dan Aplikasinya dalam Pendidikan Jasmani dan Olahraga. Jakarta: Proyek Pengembangan LPTK.

Rahyubi, H. (2012). Teori-Teori Belajar dan Aplikasi Pembelajaran Motorik. Majalengka: Referens.

Rosenbaum, P., Paneth, N., Leviton, A., Goldstein, M., Bax, M., Damiano, D., ... Jacobsson, B. (2007). A report: the definition and classification of cerebral palsy April 2006. Developmental Medicine \& Child Neurology, 49(2), 8-14. https://doi.org/10.1111/j.1469-8749.2007.tb12610.x

Santrock, J. W. (2011). Perkembangan Masa Hidup. (Widyasinta, Ed.). Jakarta: Erlangga.

Santrock, J. W. (2012). Psikologi Pendidikan: Educational Psychology Buku 1. Jakarta: Salemba Humanika.

Schmidt, R. A. (1988). Motor Control and Learning (5 ed.). United States: Human Kinetics.

Schmidt, R. A., Lee, T. D., Winstein, C. J., Wulf, G., \& Zelaznik, H. N. (2019). Motor Control and 
JURNAL SPORTA SAINTIKA

P-ISSN 2505-5651

E-ISSN 2579-5910

Learning: A Behavioral Emphasis (6 ed.). United States: Human Kinetics.

Soejanto. (1987). Fisiologi Manusia. Bandung: Rosdakarya.

Sukadiyanto. (1997). Penentuan tahap Kemampuan Motorik Anak Sekolah Dasar (Majalah IImiah). Yogyakarta: FPOK IKIP.

Sukamti, E. R. (2007). Diktat Perkembangan Motorik. Yogyakarta: UNY.

Sumarmo, M. (1982). Neuro Anatomi. Jakarta: Indira.

Tarigan, B. (2011). Optimalisasi Pendidikan Jasmani dan Olahraga Berlandaskan Ilmu Faal Olahraga. In Pidato Pengukuhan Guru Besar dalam Bidang Pedagogi Olahraga. Bandung: Fakultas Pendidikan Olahraga dan Kesehatan, Universitas Pendidikan Indonesia.

Voelcker-Rehage, C. (2008). Motor-skill learning in older adults-a review of studies on age-related differences. European Review of Aging and Physical Activity, 5(1), 5-16. https://doi.org/10.1007/s11556-008-0030-9

Wardell, S. A. (2007). Developmental Differences Of Elementary, Middle and High School Students. Diambil dari http://www.selfgrowth.com/ articles/Developmental_Differences_Of_ Elementary_Middle_And_High_School_Students.html

Widati, S., Sutisna, N., \& Widya, M. (2010). Hand Out Mata Kuliah: Bina Diri Dan Bina Gerak (BDBG). Bandung: FIP UPI.

Winarno, M. E. (1995). Belajar Motorik. Malang: Proyek OPF IKIP Malang.

Winarno, M. E. (2012). Pengembangan Karakter Bangsa melalui Pendidikan Jasmani \& Rohani. Malang. 